Available online at: https://researchsynergy.org/ijrse

International Journal of Research in STEM Education (IJRSE)

ISSN 2721-2904 (Online) | 2721-3242 (Print)

Volume 3 Number 2 (2021): 18-27

\title{
Assessment for Learning and Feedback in Chemistry: A Case for Employing Information and Communication Technology Tools
}

\author{
Johnson A. Opateye1, Daniel Raphael Ejike Ewim² \\ ${ }^{1}$ National Open University of Nigeria, Nigeria \\ ${ }^{2}$ Durban University of Technology, South Africa
}

\begin{abstract}
Assessment is essential in the learning and teaching process. In chemistry teaching, the deployment of assessment to ascertain the levels of assimilation and understanding of concepts being taught in the class is considered central in the learning process. Through the assessment for learning, teachers check students' understanding and get valuable feedback data on students' learning. This data is used to modify and improve instruction. The educational world order has drastically changed due to the emergency of COVID-19 that influenced the modes of educational delivery at such a time like this. The only option to deliver learning and assessment processes is the deployment of technology to be able to meet the demands of pandemics and its associational protocols. Information and Communication Technology (ICT) affects every facet of life, including education. Therefore, this paper examined the nature of the assessment of chemistry learning and the ICT tools required to drive the assessment procedures. In addition, it discussed the ICT feedback mechanisms in assessing the learning process in chemistry. Consequently, the paper suggested that chemistry teachers should use relevant ICT tools to monitor students' academic progress and foster ICT-driven effective feedback for assessment of chemistry learning. As a result, ICT should be deployed to assist chemistry teachers in carrying out assessment for learning to diagnose learners' understanding and difficulties during the process of instruction.
\end{abstract}

Keywords: Assessment for learning; Information and communications technology tools; Chemistry; Learning feedback; Chemistry teachers

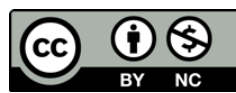

This is an open access article under the CC-BY-NC license.

\section{INTRODUCTION}

Science education arose from Victorian society's understanding, and it had shifted from a rural civilization to one controlled by and dependent on scientific and technological knowledge. This progress led to the awareness that the only way to keep this new civilization going was to ensure that a large number of individuals were trained in science and technology. While there was no argument regarding the importance of adding science into the curriculum, the nature and substance of such science education have been a source of heated discussion since then (Osborne \& Hennessy, 2003). On the one hand, those who would emphasise the essence for science education to advance knowledge and understanding of the rudimentary scientific principles that forms the basis on which the building rests, and others who would claim for emphasising the processes of scientific thinking, it was argued that opposing schools of thought have emerged. The dominating curricular model has focused on science education as a pre-professional preparation for the careers of nowadays young learners who will become tomorrow's scientists.

The growth of a highly competitive and integrated economy, rapid scientific and technical advancements, and a growing knowledge base will all continue to have a major impact on our lives. Like other science electives, chemistry will provide a platform for improving scientific literacy and creating critical scientific knowledge and abilities for lifetime learning in science and technology to tackle the challenges posed by

Corresponding author:

jopateye@noun.edu.ng; daniel.ewim@yahoo.com

DOI: https://doi.org/10.31098/ijrse.v3i2.660

Research Synergy Foundation 
International Journal of Research in STEM Education (IJRSE), Vol. 3 (2), 18-27

Assessment for Learning and Feedback in Chemistry: A Case for Employing Information and

Communication Technology Tools

Daniel Ewim, Johnson Opateye

these advancements. Chemistry is concerned with the composition, structure, and properties of matter and the interactions of various types of matter and the link between matter and energy.

It is feasible to acquire relevant conceptual and procedural knowledge by studying chemistry. Chemistry education also aids in the comprehension and appreciation of advances in engineering, medicine, and other scientific and technological domains. Furthermore, students will better grasp the relationship between science, technology, society, and the environment by learning about the contributions, concerns, and problems related to chemistry breakthroughs. Students of all abilities and aspirations will benefit from the adoption of a variety of such viewpoints and a variety of learning and teaching methodologies and evaluation practices. With the current assessment and teaching challenges occasioned by COVID-19 (Burgess \& Sievertsen, 2020; Daniels, Goegan, \& Parker, 2021; Fung \& Lam, 2020; Huang, 2020; Kaufman, Petkova, Bhui, \& Schulze, 2020; Middleton, 2020; Ripoll, Godino-Ojer, \& Calzada, 2021), there is not a better time to look at the use of ICT tools to engage assessment for learning and feedback in chemistry classroom instruction.

\section{OVERVIEW OF ASSESSMENT, TYPES, AND FEATURES}

Assessment is a means of using different procedures to get information on how students perform during learning engagements. Such assessment includes essay tests with extended responses and performance of authentic tasks using practical activities in the laboratory. The assessment provides answers to the question, "How well does the individual perform?" A test is a tool for ascertaining learners' academic performance, traits, and skills during exposure to learning content using a set of questions to elicit them. A test is a form of assessment and answers the question, "How well does the individual perform - either in comparison to others or in comparison with normative performance of tasks?" Measurement is the process of assigning a numerical value of the extent to which an individual shows a particular characteristic trait. Measurement answers the question, "How much?" Bearing these definitions in mind, the assessment process gives insight into the connection among the student learning, development, and use of relevant tools to deploy them.

When the assessment is integrated with learning content development, the learning experience is enhanced, and its scope is widened. (Linn, Gronlund, \& Davis, 2001) saw assessment as a unified method that ascertains the kind and level of student learning and development, and these processes become more effective if assessment principles and guidelines are followed. The assessor needs to clearly spell out what is to be assessed with its importance in the assessment process. An appropriate assessment procedure should be chosen because of its relevance to the attribute or performance to be measured. All-embracing assessment requires a variety of strategies to administer to the learners. Other principles are that proper handling of assessment processes requires an identification of their weaknesses knowing that is not an end itself but a means to an end. Another aspect to consider in assessment is the roles of all stakeholders such as students, teachers, and educational administrators in using technology to develop, administer, and utilize assessment during the COVID-19 pandemic.

Assessment procedures are of various types ranging from assessment of learning (summative), assessment as learning (knowledge-based), and assessment for learning (formative). Summative 
International Journal of Research in STEM Education (IJRSE), Vol. 3 (2), 18-27

Assessment for Learning and Feedback in Chemistry: A Case for Employing Information and

Communication Technology Tools

Daniel Ewim, Johnson Opateye

assessment assists in making decisions about student achievement at one point or the other in the learning process or unit of study at the end, of course, project, semester, unit, and year. It can be used formally to determine the level of attainment of learning outcomes set out at the beginning of the course and could be measured through tests, laboratory practices, assignments, projects, presentations, and the attainment of program objectives and teaching effectiveness.

(Johnson \& Johnson, 2002) emphasized that formative assessments are undertaken at specific periods during a course of study or instructional process to ascertain the improvement made in learning so as to give feedback on the attainment of learning objectives. When the feedback is received, the learners develop activities to enhance their knowledge. Also, formative assessments also help the teachers depict their ability on the kind of instructions employed in the classroom. Another major feature of formative assessments is that they are not used to grade either the learner or the instructor but to pinpoint learning challenges. (Gronlund, 1998) described performance assessment as a form of assessment that requires students to display their comprehension of concepts and skills when a certain task or set of tasks are performed.

Formative assessment is the practice of measuring the student's progress of achievement that often occurs during everyday learning experiences and instructional processes. Such assessment for learning includes informal observations throughout the term, semester, or session and to ensure students' continued academic advancement to provide prompt and meaningful feedback. With this assessment, teachers can modify and extend their instructions and adjust their learning and teaching strategies to the students' aspects of students' learning difficulties. This is very relevant and helpful during interactive group work activities. Key features of assessment for learning are:

- Clearness of studying intentions,

- distributing learning intentions and success criteria among students,

- making available clear feedback and approaches for promoting expanded learning, and

- active and collaborative deliberations using assessment information to improve and recognise the next step to take in learning

To exhibit these features, assessment for learning (AFL) and Information and Communication Technology (ICT) is to be linked to enhance the learning intentions in chemistry teaching and learning.

\section{JUSTIFICATION FOR ASSESSING WITH TECHNOLOGY}

Technology can be used to retrieve information readily beyond our imaginations and is capable of making scientific endeavors a channel to improve students' comprehension of information, concepts, and new ideas. Animations and simulations become a source of prospects to behold phenomena and try predictions that cannot be explored with practical experiments in the classroom which leads to boosting learners' understanding and studying of science-related subjects. Though a lot of research confirmed the connection between the deployment of digital technology and learning, the utilisation of digital technology changes assessment orders in most schools. Some of that research is concentrated on the use of technology to substitute conventional assessment methods, which is looking at the same thing from different perspectives (Raikes \& 
International Journal of Research in STEM Education (IJRSE), Vol. 3 (2), 18-27

\section{Assessment for Learning and Feedback in Chemistry: A Case for Employing Information and \\ Communication Technology Tools \\ Daniel Ewim, Johnson Opateye}

Harding, 2003) emphasised that using a computer-based assessment will administer tests using a minimal cost which results in greater flexibility regarding the administration of the test, allow immediate marking and giving of feedback, minimise the possibility of mistakes, and allow for more quality test items through the application of adaptive testing. Although the benefit of computerbased testing cannot be over-emphasised, not all colleges have equal opportunity to use technology, and not all students have the same computer knowledge or skill, which might affect the purpose of the test scores (Russell, Goldberg, \& O'connor, 2003). In order to consider all students whatever be the level of available technology, (Raikes \& Harding, 2003) opines that there should be a period of change to forestall inequity and suggests that computer-based and conventional pen-on-paper tests are undertaken at the same time. More attention is needed to be paid to guarantee that there is a similarity in the paper-based, computer-based assessments and that the hardware and software components are available and reliable.

Technology and assessment could be classified into three categories that could be focused on (McFarlane, 2003). The first is that Information and Telecommunication Technology is employed to judge the same thing in different ways. That is, the computer assessment caused the change of traditional assessment strategies. These led to the utilisation of automated test items, especially the objective related like multiple choice that has the options out which computers can identify the correct option with ease and saving of time though the assessment standard does not change. Secondly, some difficult content and knowledge may be hard to assess using conventional assessment; computers are effective for assessing the same thing in diverse ways. Computers are the solution for reliable results of the assessment. And lastly, the focus technology-based assessment needs to be checked in relation to the use it measures knowledge and skills derived from computer-based learning. In chemistry, therefore, the assessment standards in computerbased testing are different from those of essay-type of tests. When examining the 21st-century skills and the transformation in technology, there are changes in stating the learning objective to reflect the competence-based that the technology age emphasizes made the assessment criteria of this age different from the traditional modes (McFarlane, 2003; Ridgway \& McCusker, 2003). Teachers and instructors of chemistry are to embrace the use of technology-based testing to meet the demands

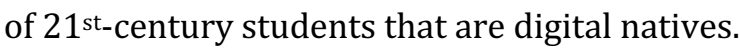

In chemistry, students can function with complex and real assessment data that would not be easily analysed without the application of technology (Ridgway \& McCusker, 2003). When (Wirth \& Klieme, 2003) examined problem-solving in chemistry, they believed that there are two types of competence required of the chemistry students, namely, analytical features where the tangible goals are set, with explicit relevant information can be arrived at by reasoning. The second is on dynamic aspects where desired information is not accessible or directly observable. The dynamic response to test items obtainable in a technology-based test provided to learners when assessing the dynamic aspects of problem-solving is beyond (Wirth \& Klieme, 2003) the achievement of conventional paper-oriented assessments.

\section{ICT TOOLS FOR CHEMISTRY ASSESSMENT OF LEARNING}

Chemistry students learn through participation in lectures by listening and taking notes, practicing technical skills, reading textbooks and papers, producing papers, presenting papers, and project- 
based laboratory works. During these processes, the instructors use the following assessment methods: written examinations, oral examinations, laboratory assessments, problem-based exercises, tests, and assignments. During teaching and learning, teachers administer these forms of assessment coupled with the use of ICT tools to foster effective learning of chemistry. Table 1 shows assessment modes and specific chemistry contents are linked with ICT tools.

Table 1: Linking assessment for learning to ICT tools and Chemistry related concepts

\begin{tabular}{|c|c|c|c|}
\hline $\begin{array}{l}\text { Assessment for } \\
\text { Learning }\end{array}$ & Type & ICT Tools & $\begin{array}{c}\text { Chemistry related } \\
\text { concepts }\end{array}$ \\
\hline $\begin{array}{l}\text { Lesson-based } \\
\text { assessment }\end{array}$ & Oral quizzes & $\begin{array}{l}\text { PAS, Computer, } \\
\text { Computer PowerPoint } \\
\text { Presentation (PPT), } \\
\text { Internet browsing, e- } \\
\text { learning (Skype, MS } \\
\text { Teams, Google, Zoom, } \\
\text { make a video (write a } \\
\text { script and } \\
\text { produce/make a } \\
\text { video) } \\
\text { Presentation to the } \\
\text { camera, CAI, Digital } \\
\text { cameras } \\
\text { Printer, public address } \\
\text { system, Moodle } \\
\text { software and } \\
\text { Photocopier }\end{array}$ & $\begin{array}{l}\text { All } \\
\text { Chemistry topics }\end{array}$ \\
\hline $\begin{array}{l}\text { Practising technical } \\
\text { skills }\end{array}$ & $\begin{array}{l}\text { Students' } \\
\text { demonstrative } \\
\text { activities }\end{array}$ & $\begin{array}{l}\text { Computer-aided } \\
\text { assessment, Online } \\
\text { graphics, Add or edit } \\
\text { to a Wikipedia article, } \\
\text { Pen Drive, iPod } \\
\text { iPad, Web boards, } \\
\text { simulation software }\end{array}$ & $\begin{array}{l}\text { Separation of } \\
\text { mixtures; Acids, } \\
\text { bases, and salts. } \\
\text { Electrochemistry }\end{array}$ \\
\hline Laboratory & $\begin{array}{l}\text { Practical manipulative } \\
\text { assessment }\end{array}$ & $\begin{array}{l}\text { Computer simulations, } \\
\text { YouTube, Online group } \\
\text { work, } \\
\text { Observation of real or } \\
\text { simulated professional } \\
\text { practice }\end{array}$ & $\begin{array}{l}\text { Quantitative and } \\
\text { Qualitative } \\
\text { analyses }\end{array}$ \\
\hline
\end{tabular}


International Journal of Research in STEM Education (IJRSE), Vol. 3 (2), 18-27

Assessment for Learning and Feedback in Chemistry: A Case for Employing Information and Communication Technology Tools

Daniel Ewim, Johnson Opateye

\begin{tabular}{|l|l|l|l|}
\hline $\begin{array}{l}\text { Seminar } \\
\text { presentations }\end{array}$ & Rubric development & $\begin{array}{l}\text { Online itemised rubric, } \\
\text { PAS, Presentation to } \\
\text { camera, PowerPoint } \\
\text { presentation, word } \\
\text { processing application }\end{array}$ & \\
\hline $\begin{array}{l}\text { Assignment } \\
\text { Completion }\end{array}$ & Assignment. Portfolio & $\begin{array}{l}\text { Written, PowerPoint } \\
\text { presentations, } \\
\text { Telephone, Electronic } \\
\text { Portfolio, CAI, } \\
\text { WhatsApp }\end{array}$ & $\begin{array}{l}\text { All chemistry } \\
\text { topics }\end{array}$ \\
\hline Model formation & Creative / Innovative & $\begin{array}{l}\text { Electronic rubric, } \\
\text { Computer graphics }\end{array}$ & $\begin{array}{l}\text { Atomic models, } \\
\text { Hydrocarbons }\end{array}$ \\
\hline
\end{tabular}

Communication tools for AFL could be categorised into two: Synchronous and Asynchronous. In asynchronous communication, teachers and students have delayed responses to the questions for learning assessment. Such communication tools such as e-mails, blogs, wikis, newsgroups, podcasts, YouTube, audio-graphics online forums, and scanners, as shown in Figure 1. All these aid effective asynchronous responses to questions. Synchronous tools enable teachers to communicate assessment items to learners with immediate response and feedback in real-time with the instructor. Examples of synchronous communication tools are Skype, MS Teams, Google Talk, MSN, Yahoo Messenger, Video messaging, Telephone calls, interactive whiteboards, etc. (Figure 2).

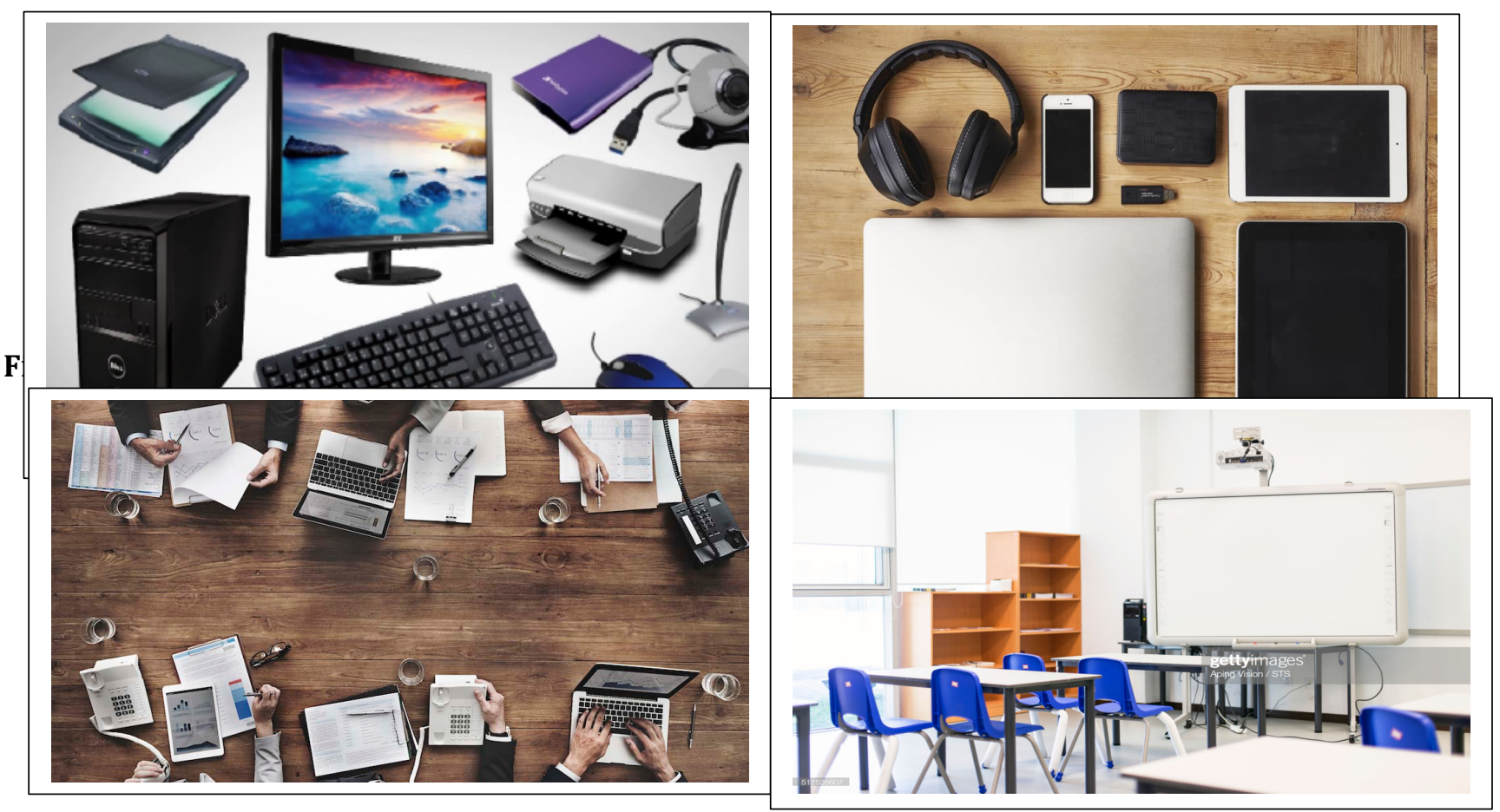

Figure 2: Synchronous and asynchronous communication tools 
International Journal of Research in STEM Education (IJRSE), Vol. 3 (2), 18-27

Assessment for Learning and Feedback in Chemistry: A Case for Employing Information and

Communication Technology Tools

Daniel Ewim, Johnson Opateye

\section{GIVING ASSESSMENT FEEDBACK WITH ICT TOOLS}

Feedback is an important aspect of learning, and it is properly utilized, it is a powerful tool to moderate and improve students' achievement (Hattie \& Timperley, 2007). (David Nicol, 2007) also pointed out some main functions of feedback in the form of justifying how students' responses are scored and graded, pinpointing areas of reward for the quality of learners work, directing students on what to do in order to take to enhance effective learning, inspiring students to be active when taking their assessment and improve students' ability to monitor, regulate and evaluate their own learning as a form of self-assessment. Constructive feedback could be beneficial to student learning if it is given at the appropriate time. When evaluating the quality of students' work, the focus should be on how the learner could improve on learning and the work they are presenting for assessment. Feedback needs to be prompt, and the work being assessed is still fresh in the minds of the learners and before proceeding to the next learning activity. Feedback must carry a great positive effect on the learners, aim at providing for individual learning needs, be connected to distinctive assessment criteria, and be embraced by a learner in time to help the understanding of benefit subsequent assignment. (Boud \& Molloy, 2013) also asserted that feedback should be informative, supportive, frequent, and specific enough to guide students learning and work. Feedback is worthwhile when it is gotten, comprehended, and carried out. Chemistry students can analyze, deliberate, and take necessary actions on feedback in order to foster and enjoy the quality of the feedback when the instructor gives it. (D Nicol, 2007; David Nicol, 2007). Through the interaction students have with feedback, they come to understand how to develop their learning.

ICT could be employed to facilitate feedback after assessment for learning has taken place to organise learning in the form of folders, labels, and notebooks. Tracking academic progress and collaboration in which peer editing students can respond to and edit comments. ICT also is versatile, accessible, and could be cloud-based in keeping relevant information. It is also possible to keep feedback manageable using ICT because it aids organisation, paperless, changes assessment tasks, develops or uses existing rubrics, or uses existing chemistry quizzes. Relevant ICT tools for assessment feedback are Rubistar, Microsoft Office, Google Docs, PDF text, Learning Management System (LMS) (e.g., Moodle, Blackboard, and Zoom), DROPitTOme, Dropbox, Office Podcast, Comment sections of YouTube/blogs/wikis. Other are Emails, Evernote to create audio notes and audio feedback, and other Apps such as Socrative Quizlet, Camtasia studio for recording students' responses to chemistry formative assessment questions. Telephone operations such as making calls, sending messages on WhatsApp and telegram platforms, and text messages provide students with feedback after assessments have been undertaken.

\section{ADVANTAGES OF ICT FACILITATED AFL}

Having considered various ICT tools that facilitate assessment for learning and feedback, the advantages of ICT come into focus. ICT gives an opportunity for more learner-centered instruction with assessment and fosters greater opportunity for communication between teacher-to-teacher and student-to-student and collaboration during the administration of assessment for learning. It gives greater exposure to assessment that will develop competency-based necessary for the world of work for which chemistry teachers use different types of technology to drive assessment. ICT is important in creating greater enthusiasm for learning amongst students when answering chemistry 
International Journal of Research in STEM Education (IJRSE), Vol. 3 (2), 18-27

Assessment for Learning and Feedback in Chemistry: A Case for Employing Information and

Communication Technology Tools

Daniel Ewim, Johnson Opateye

assessment questions with greater provision of new sources of assessment information and knowledge to chemistry teachers. Chemistry students are also prepared with additional resources to assist resource-based assessment. ICT leverages to help and administer assessment for the benefit of learners and teachers across the curriculum and widen the opportunity to quality education delivery to learners at all levels of the educational system.

\section{OBSTACLES TO SUCCESSFUL INTEGRATION OF ICT TOOLS FOR AFL AND FEEDBACK}

In spite of the capacity of ICT in school chemistry assessment for learning, it is necessary to examine some factors that can limit its appropriate integration to classroom assessment. There are hindrances that are connected to resources availability, the skills, and low levels of training and development programmes on the ground to teachers who use ICT, personal and cultural beliefs of teachers who utilise ICT in their instruction, nature of institutions, and other factors which may influence the use of ICT in chemistry content delivery and education. The findings of research carried out by Becta points out that there are four categories of issues that slowed down the ICT integration in schools. These are resource-related, which relates to the development of skills, knowledge, and computer experience; disposition and personality of teachers; institutional and cultural biases (Becta, 2003). (Pelgrum, 2001) claimed that the most rated obstacle to integrating ICT in teaching is the inadequate resources, especially when the teachers were asked to classify their personal opinions about the possible challenges to ICT use. Institution-induced obstacles are insufficient resources both within and outside the school, and technology rigidity was assessed lowest and teacher-related issues such as lack of skills, knowledge, and time were ranked highest. (Law \& Chow, 2008a, 2008b) also emphasised that inculcation of ICT into the assessment for learning and feedback could also result in computers restraining students' imaginations, overdependence on ICT lowers students' critical thinking and analytical skills. Computer-based assessment has physical side-effects such as vision impairment, and chemistry students may be concentrating more on the ICT aspect that does not relate to the content of focus at a particular time, which may easily divert their attention from their learning.

In addition, students could also be prone to neglect learning resources other than the computer, telephones, and internet and to concentrate on superficial presentations and direct copying and surfing from the Internet. Students may also be limited in using oral skills and handwriting in answering questions that involve supply response, and weaker students may have problems with working independently and may need more support from the teacher. The cost of subscribing to data for online assessment among students may hinder the effective usage of ICT tools when necessary. Electricity powers up most of the ICT tools, where power is epileptic to charge such gargets may cause a delay in responding to AFL questions that might be posted online.

\section{CONCLUSION}

Assessment for learning programs is based on the premise that formative assessment guides and facilitates learners to achieve to attain optimum potential. Chemistry teachers could take advantage of ICT tools to pose questions to students that would facilitate learning. ICT tools could also assist in giving immediate feedback to students on their responses to questions, which is plunged to chemistry students' remediating their areas of difficulties to learn better. In spite of challenges that are facing effective 
International Journal of Research in STEM Education (IJRSE), Vol. 3 (2), 18-27

\section{Assessment for Learning and Feedback in Chemistry: A Case for Employing Information and \\ Communication Technology Tools \\ Daniel Ewim, Johnson Opateye}

deployment of ICT tools to facilitate teachers' classroom assessment, ICT tools are to make an assessment for learning and its feedback more effective and result-oriented.

\section{SUGGESTIONS}

In view of the foregoing, the following suggestions are made:

1. Serving chemistry teachers should be trained to be ICT literate through in-service education to embrace the use of ICT tools for assessment.

2. Government should provide ICT facilities in schools for teachers to use for assessment to foster learning.

3. The government should provide alternative electricity supply to every school by giving generators and installing solar panels to ICT laboratories to foster effective use for assessment.

4. In rural areas, schools in the same neighbourhood be linked together schools via learning network cells and wireless technologies for ICT tools to be deployed irrespective of the location of the schools.

5. Technical supports for ICT needs are to be regionalised to make teachers get solutions to technical challenges promptly when using ICT assessment in the classroom.

6. ICT sensitisation programmes should be piloted for assessment purposes making the digital learning materials related to the curriculum the tutors are to teach and assess on a regular basis.

7. It is also important to ensure effective professional capacity building in the technical and pedagogical use of ICT, and these should reflect the technical installations for chemistry teachers to effectively implement assessment for learning in the classroom.

8. Teachers should make sure that assessment for learning has been used to benefit all learners and not a portion of the learners to ensure equity and social justice to maximise the gains of both formative and summative assessments in the classroom.

9. Proper application of ICT tools informative assessments is essential for associated learning processes to occur effectively in the 21st-century era of COVID-19 when social distancing is limiting human physical contact in the classroom.

\section{REFERENCES}

Becta, D. (2003). What the research says about barriers to the use of ICT in teaching. Retrieved from http://partners.becta.org.uk/uploaddir/downloads/page_documents/research/wtrs_bar riersinteach.pdf

Boud, D., \& Molloy, E. (2013). Rethinking models of feedback for learning: the challenge of design. Assessment \& Evaluation in higher education, 38(6), 698-712.

Burgess, S., \& Sievertsen, H. H. (2020). Schools, skills, and learning: The impact of COVID-19 on education. VoxEu. org, 1(2).

Daniels, L. M., Goegan, L. D., \& Parker, P. C. (2021). The impact of COVID-19 triggered changes to instruction and assessment on university students' self-reported motivation, engagement and perceptions. Social Psychology of Education, 24(1), 299-318.

Fung, F. M., \& Lam, Y. (2020). How COVID-19 disrupted our "flipped" freshman organic chemistry course: Insights gained from Singapore. Journal of Chemical Education, 97(9), 2573-2580.

Gronlund, N. E. (1998). Assessment of student achievement: ERIC. 
International Journal of Research in STEM Education (IJRSE), Vol. 3 (2), 18-27

Assessment for Learning and Feedback in Chemistry: A Case for Employing Information and

Communication Technology Tools

Daniel Ewim, Johnson Opateye

Hattie, J., \& Timperley, H. (2007). The power of feedback. Review of educational research, 77(1), 81112.

Huang, J. (2020). Successes and Challenges: Online Teaching and Learning of Chemistry in Higher Education in China in the Time of COVID-19. Journal of Chemical Education, 97(9), 28102814.

Johnson, D. W., \& Johnson, R. T. (2002). Meaningful assessment: A manageable and cooperative process: Pearson College Division.

Kaufman, K. R., Petkova, E., Bhui, K. S., \& Schulze, T. G. (2020). A global needs assessment in times of a global crisis: world psychiatry response to the COVID-19 pandemic. BJPsych Open, 6(3).

Law, N., \& Chow, A. (2008a). Pedagogical orientations in mathematics and science and the use of ICT. In Pedagogy and ICT Use (pp. 121-179): Springer.

Law, N., \& Chow, A. (2008b). Teacher characteristics, contextual factors, and how these affect the pedagogical use of ICT. In Pedagogy and ICT use (pp. 181-219): Springer.

Linn, R. L., Gronlund, N. E., \& Davis, K. M. (2001). Measurement and Assessment in Teaching: Merrill.

McFarlane, A. (2003). Editorial. Assessment for the Digital Age. Assessment in Education: Principles, Policy \& Practice, 10(3), 261-266. doi:10.1080/0969594032000148127

Middleton, K. V. (2020). The longer-term impact of COVID-19 on K-12 student learning and assessment. Educational Measurement: Issues and Practice, 39(3), 41-44.

Nicol, D. (2007). Formative assessment and feedback for first year success: Enhancing academic and social integration. Report prepared for QAA Scotland.

Nicol, D. (2007). Principles of good assessment and feedback: Theory and practice. Paper presented at the REAP International online conference on assessment design for learner responsibility.

Osborne, J., \& Hennessy, S. (2003). Literature review in science education and the role of ICT: Promise, problems and future directions (Vol. 6): Futurelab London, United Kingdom.

Pelgrum, W. J. (2001). Obstacles to the integration of ICT in education: results from a worldwide educational assessment. Computers \& Education, 37(2), 163-178.

Raikes, N., \& Harding, R. (2003). The horseless carriage stage: Replacing conventional measures. Assessment in Education: Principles, Policy \& Practice, 10(3), 267-277.

Ridgway, J., \& McCusker, S. (2003). Using computers to assess new educational goals. Assessment in Education: Principles, Policy \& Practice, 10(3), 309-328.

Ripoll, V., Godino-Ojer, M., \& Calzada, J. (2021). Teaching Chemical Engineering to Biotechnology students in the time of COVID-19: Assessment of the adaptation to digitalization. Education for Chemical Engineers, 34, 94-105.

Russell, M., Goldberg, A., \& O'connor, K. (2003). Computer-based testing and validity: A look back into the future. Assessment in Education: Principles, Policy \& Practice, 10(3), 279-293.

Wirth, J., \& Klieme, E. (2003). Computer-based assessment of problem solving competence. Assessment in Education: Principles, Policy \& Practice, 10(3), 329-345. 